\title{
Predation Losses of Cattle in Alberta
}

MICHAEL J. DORRANCE

\section{Abstract}

Coyotes (Canis latrans), black bears (Ursus americanus), and wolves (Canis lupus) were reported responsible for 35,31 , and $16 \%$, respectively, of confirmed predation losses of cattle in Alberta during 1974-78. Coyotes selected for calves over adults, and adults over yearlings, black bears selected for calves over yearlings, and yearlings over adults, and wolves selected for calves and yearlings over adults. Predation of cattle by coyotes, bears, and wolves peaked during March-June, May-July, and AugustSeptember, respectively.

Little information is available on predation losses of cattle, even though the value of losses from predation are comparable for cattle and sheep in the United States (Anon. 1978, Gee 1979). In Alberta, the value of cattle lost to predation from coyotes, black bears, and wolves exceeds that of other species of livestock.' This paper describes the monthly chronology and age distribution of predation losses of cattle in Alberta, Canada during 1974-78.

\section{Methods}

Since 1974, the Alberta government has paid compensation for predation losses of livestock reported by producers and investigated by government personnel. Criteria used for identification of predation were described by Roy and Dorrance (1976). Death or injury of livestock was classified as (1) confirmed as predation, (2) predation probable but not confirmed, (3) other than predation, and (4) undetermined. Data recorded included numbers and species of livestock killed or wounded, age of livestock, estimated body weight, herd or flock size, date of predation, predator responsible, and legal land description. This paper summarizes data of confirmed losses of cattle from predation during 1974-78 for which the date of predation could be determined within 1-4 days.

Data were separated into five major ecosystems; i.e. mixed forest, northern parkland, southern parkland, foothills and mountains, and prairie (Dorrance and Roy 1976). The parkland was subdivided into a northern and southern unit separated by the Bow River because distribution and population densities of predators appeared to differ between these areas. Data from the foothills and mountains were combined because of relatively low numbers of cattle.

An index of susceptibility of cattle to predation was calculated by dividing the total number of cattle killed or wounded by each predator in each ecosystem by the percentage of all cattle within the ecosystem. The index represents a valid estimate of susceptibility of cattle to predation if (1) the percentage of predation losses reported by stockmen remained constant among ecosystems, and (2) the probability of finding and identifying predation losses remained constant among ecosystems. The validity of the first assumption is unknown. Increased forest cover and rugged topography probably reduced the probability of finding predation losses; thus, the index is probably biased downward in the foothills

\footnotetext{
Author is head, Problem Wildlife Section, Alberta Environmental Centre, Bag 4000, Vegreville, Alta, T0B 4L0, Canada.

Acknowledgment is made to Dr. G.R. Whenham (deceased), Alberta Agriculture, W.N. McLachlan, Alberta Energy and Natural Resources, and P. Erickson for special assistance.

Unpublished data. Summers, G.W. December 1980. Alberta Agriculture, 6909-I I6 Street, Edmonton, Alberta T6H 4 P2.
}

and mountains, mixed forest, and to a lesser degree in the northern parkland.

Selectivity by predators for calves, yearlings, and adults was evaluated with a chi-square test between age composition of predator kills and age composition of 36,581 cattle ( 87 calves:36 yearlings: 100 adults) pastured on provincial grazing reserves during 1976-78. ${ }^{2}$

\section{Results and Discussion}

Confirmed predation losses totaled 1,520 cattle killed or wounded in Alberta during 1974-78. Coyotes, black bears, and wolves were the major predators of cattle and were reported responsible for 35,31 , and $16 \%$ of confirmed losses, respectively. An additional $8 \%$ were attributed to either wolves or bears. Predators responsible for the remaining $10 \%$ were classified as dog family $(\mathrm{n}=52), \operatorname{dog}(\mathrm{n}=7)$, cat family $(\mathrm{n}=8)$, mountain lion (Felis concolor) $(\mathrm{n}=15)$, lynx (Lynx canadensis) $(\mathrm{n}=3)$, grizzly bear (Ursus arctos) $(\mathrm{n}=11)$, golden (Aquila chrysaetos) or bald (Haliaeetus leucocephalus) eagle $(n=3)$, and unknown $(n=42)$.

About $4 / 5$ of the predation losses occurred in the mixed forest and northern parkland where $2 / 3$ of the cattle were raised (Table 1). However, susceptibility of cattle to predation was 4-9 times greater in the foothills and mountains than in the mixed forest, 2-9 times greater in the mixed forest than in the northern parkland, and comparatively low in the prairie and southern parkland (Table 1). In general, susceptibility of cattle to predation increased with increased forest cover and was accentuated by rugged topography.

Age composition differed significantly among cattle killed by coyotes, bears and wolves $(P<0.01)$. Compared with a ratio of 87 calves:36 yearlings: 100 adults on provincial grazing reserves, ${ }^{2}$ coyotes selected for calves over adults $(P<0.01)$, and adults over yearlings $(R<0.05)$; bears selected for calves over yearlings, and yearlings over adults $(R<0.01)$; and wolves selected for calves and yearlings over adults $(P<0.01)$ (Table 2 ).

All major predators selected for calves over adults (Table 2), but coyotes were the most selective $(P<0.01)$. Seventy-eight percent of the calves killed by coyotes were 1 month of age or less, and $32 \%$ were killed at I day of age (Fig. 1). Thus, monthly chronology of coyote predation coincided with the calving season and peaked sharply during March-June in Alberta (Fig. 2). Unlike bears and wolves, coyotes selected for adults over yearlings (Table 2, $P<0.05$ ), probably because coyote predation of older age classes of cattle was most often associated with calving or defense of calves.

Black bears selected for calves over yearlings, and yearlings over adults, and were intermediate in selectivity between coyotes and wolves (Table $2, P<0.01$ ). The pronounced increase in bear predation between April and May reflected emergence of bears from hibernation and departure from den sites (Tietje and Ruff 1980), and movement of cattle to more remote pastures. Bear predation peaked during May-July and ideclined during August and September (Fig. 2) probably because alternative sources of food (e.g. berries) were available. The gradual decline in percentage of kills older than 5 months of age (Fig. 1) and selectivity of calves over yearlings also suggest that the decline in bear predation during late

2 Unpublished data. McLachlan. W.N. December 1980. Alberta Energy and Natura Resources, 9915-108 Street, Edmonton, Alberta TSK 2C9. 
Table 1. Distribution of cattle, and susceptibility of cattle to predation in Alberta. Indices of susceptibility of cattle to predation were calculated by dividing the total number of cattle killed or wounded by the percentage of cattle within the ecosystem. Numbers of cattle killed or wounded are in parentheses.

\begin{tabular}{|c|c|c|c|c|c|}
\hline \multirow[b]{2}{*}{ Ecosystem } & \multirow{2}{*}{$\begin{array}{l}\text { Distribution } \\
\text { of cattle (\%) }\end{array}$} & \multicolumn{4}{|c|}{ Relative susceptibility of cattle to predation } \\
\hline & & Coyote & Black bear & Wolf & Mountain lion \\
\hline Foothills and mountains & 1 & $94(94)$ & $58(58)$ & $63(63)$ & $1(1)$ \\
\hline Mixed forest & 17 & $10(176)$ & $14(232)$ & $9(149)$ & $0(0)$ \\
\hline Northern parkland & 48 & $5(221)$ & $4(188)$ & $1(29)$ & $0(14)$ \\
\hline Prairie & 26 & $2(55)$ & $0(0)$ & $0(0)$ & $0(0)$ \\
\hline Southern parkland & 8 & $1(6)$ & $1(5)$ & $0(0)$ & $0(0)$ \\
\hline
\end{tabular}

'Data provided by Alberta Agriculture Statistics Branch, December, 1980

Table 2. Age composition of cattle killed by predators.

\begin{tabular}{|c|c|c|c|c|c|}
\hline \multirow[b]{2}{*}{ Predator } & \multirow[b]{2}{*}{$\begin{array}{l}\text { Number of } \\
\text { cattle }\end{array}$} & \multicolumn{3}{|c|}{ Percent } & \multirow[b]{2}{*}{$\begin{array}{l}\text { Ratio } \\
\text { calves:yearlings: } 100 \text { adults }\end{array}$} \\
\hline & & Calves & Yearlings & Adults & \\
\hline Coyote & 532 & 93 & 1 & 6 & $1547: 16: 100$ \\
\hline Black bear & 466 & 71 & 11 & 18 & $394: 61: 100$ \\
\hline Wolf & 241 & 54 & 23 & 23 & $235: 100: 100$ \\
\hline Mountain lion & 13 & 69 & 23 & 8 & \\
\hline
\end{tabular}

summer and fall resulted from increased size of calves.

Wolves selected for calves and yearlings over adults $(P<0.01)$, but exhibited no apparent preference between calves and yearlings $(P>0.05$, Table 2 ). Most calves killed by wolves were 5-9 months of age (Fig. 1). Thus, an increase in the size of calves apparently did not deter predation by wolves. Wolf predation did not peak until August and September (Fig. 2), although calves were available

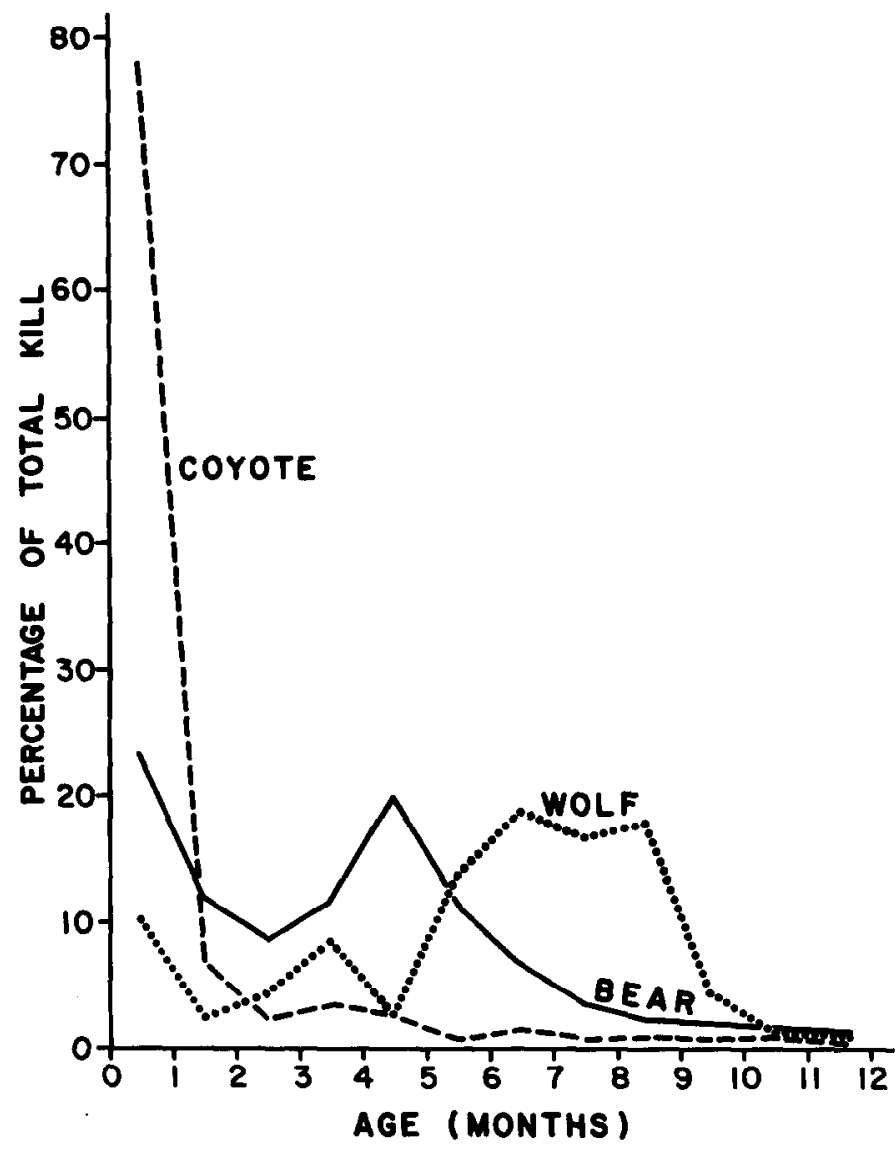

Fig. 1. Age distribution of calves killed by predators. throughout the summer. Wolves tended not to prey on the youngest calves, perhaps because preferred, alternate sources of food were more available during May-July. During early summer wolves select newborn fawns and calves of wild ungulates, which are helpless unless defended by an adult (Mech 1970:176). Perhaps wolves prefer wild ungulates, but switch to domestic cattle in late summer when fawns and calves of wild ungulates become more difficult to catch.

A small sample size prevented statistical analysis of mountain lion predation, but they were apparently intermediate between coyotes and wolves in selectivity for age classes of cattle (Table 2).

Closer surveillance of cattle during calving time should reduce predation by coyotes, particularly in the forested regions of Alberta. Movement of cows with small calves to remote, forested pastures should be deferred, to reduce the probability of predation by coyotes and bears. In areas with a history of wolf predation, it may be desirable to develop rotational grazing systems so that cattle are removed from remote forested pastures during late summer.

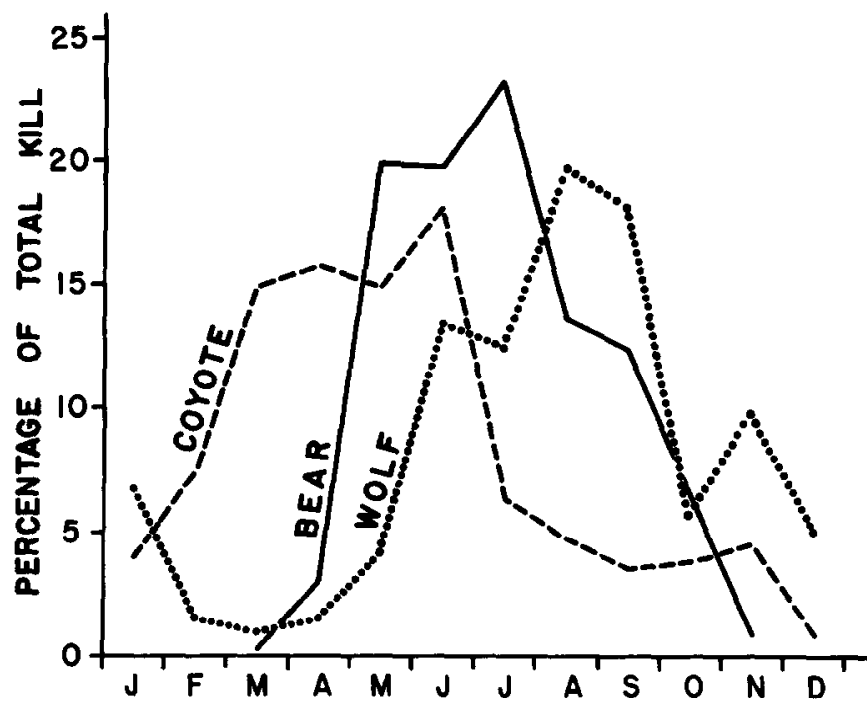

Fig. 2. Monthly chronology of predation losses of cattle in Alberta. 


\section{Literature Cited}

Anonymous. 1978. Predator damage in the West:a study of coyote management alternatives. U.S. Fish and Wildl. Serv. 168 p.

Dorrance, M.3., and L.D. Roy. 1976. Predation losses of domestic sheep in Alberta. J. Range Manage. 29:457-460.

Gee, C.K. 1979. Cattle and calf losses to predators-feeder cattle enterprises in the United States. J. Range Manage. 32:152-154.
Mech, L.D. 1970. The wolf: the ecology and behavior of an endangered species. The Natural History Press, Garden City, New York. 384 p.

Roy, L.D., and M.J. Dorrance. 1976. Methods of investigating predation of domestic livestock. Alberta Agr., Edmonton. 54 p.

Tietje, W.D., and R.L. Ruff. 1980. Denning behavior of black bears in boreal forest of Alberta. J. Wildl. Manage. 44:858-870.

\section{Membership in the Society for Range Management. . .}

is open to those engaged in or interested in the study. manogement, or use of range ecosysterns and the intelligent use of all range resources

includes research scientists, ranchers, govemmental agency administrators and technical personnel. teachers. students. and people from the business community

- provides members with two publications - one oriented to research (Journal of Range Management) and the other criented to practical resource manogement (Rangelands) offers opportunities for face-to-face exchonge of ideas of local, national, and international meetings of the Society.

Dues vary according to type of membership and geagraphical section. For application forms and additional information, contact the:

Executive Secretary

Society for Range Mangoement

2760 West Fifth Avenue

Denver, Colorado 80204

(303) 571-0174

\begin{tabular}{|c|c|c|c|c|c|c|c|}
\hline \multirow[b]{2}{*}{ DUES SCHEDULE } & \multirow[b]{2}{*}{ Regular } & \multirow[b]{2}{*}{ Student } & \multirow[b]{2}{*}{ Sustaining } & \multirow[b]{2}{*}{ Emeritus } & \multirow[b]{2}{*}{ Institutional } & \multicolumn{2}{|c|}{ Family } \\
\hline & & & & & & $\begin{array}{l}\text { First } \\
\text { Member }\end{array}$ & $\begin{array}{c}\text { Each } \\
\text { Additional }\end{array}$ \\
\hline ARIZONA $\ldots \ldots \ldots \ldots \ldots \ldots$ & 543.00 & S 22.00 & \$ 64.00 & \$ 30.00 & $\$ 203.00$ & $\$ 43.00$. & …..23.00 \\
\hline CALIFORNIA $\ldots \ldots \ldots \ldots \ldots$ & 45.00 & 23.00 & 68.00 & 30.00 & 225.00 & 45.00 & $\ldots \ldots 23.00$ \\
\hline COLORADO $\ldots \ldots \ldots \ldots \ldots \ldots$ & 42.00 & 22.00 & 62.00 & 29.00 & 202.00 & 42.00 & $\ldots \ldots .22 .00$ \\
\hline IDAHO $\ldots \ldots \ldots \ldots \ldots \ldots \ldots$ & 42.00 & 22.00 & 62.00 & 29.00 & 202.00 & 42.00 & $\ldots \ldots 22.00$ \\
\hline KANSAS-OKLAHOMA ....... & 43.00 & 22.00 & 62.00 & 29.00 & 203.00 & 43.00 & $\ldots \ldots .23 .00$ \\
\hline MEXICO $\ldots \ldots \ldots \ldots \ldots \ldots$ & 44.00 & 24.00 & 64.00 & 31.00 & 204.00 & 44.00 & $\ldots \ldots 24.00$ \\
\hline NEBRASKA $\ldots \ldots \ldots \ldots \ldots$ & 44.00 & 22.00 & 64.00 & 31.00 & 204.00 & 44.00 & $\ldots \ldots 24.00$ \\
\hline NEVADA $\ldots \ldots \ldots \ldots \ldots \ldots$ & 42.00 & 22.00 & 62.00 & 29.00 & 202.00 & 42.00 & $\ldots \ldots 22.00$ \\
\hline NEW MEXICO ............. & 42.00 & 21.00 & 62.00 & 29.00 & 202.00 & 42.00 & $\ldots \ldots 22.00$ \\
\hline NORTHERN GREAT PLAINS. & 43.00 & 23.00 & 63.00 & 30.00 & 203.00 & 43.00 . & $\ldots \ldots 23.00$ \\
\hline INTERNATIONAL MNTN .... & 43.00 & 23.00 & 63.00 & 30.00 & 203.00 & 43.00 & $\ldots \ldots 23.00$ \\
\hline PACIFIC NORTHWEST ..... & 45.00 & 25.00 & 65.00 & 32.00 & 205.00 & 45.00 . & $\ldots \ldots 25.00$ \\
\hline SOUTH DAKOTA .......... & 44.00 & 23.00 & 63.00 & 30.00 & 204.00 & 44.00 . & $\ldots \ldots 24.00$ \\
\hline SOUTHERN $\ldots \ldots \ldots \ldots \ldots$ & 45.00 & 25.00 & 65.00 & 32.00 & 205.00 & 45.00 . & …..25.00 \\
\hline FLORIDA $\ldots \ldots \ldots \ldots \ldots \ldots$ & 45.00 & 25.00 & 65.00 & 32.00 & 205.00 & 45.00 & $\ldots \ldots 25.00$ \\
\hline TEXAS $\ldots \ldots \ldots \ldots \ldots \ldots \ldots$ & 43.00 & 21.50 & 63.00 & 30.00 & 203.00 & 43.00 . & $\ldots \ldots 23.00$ \\
\hline UTAH $\ldots \ldots \ldots \ldots \ldots \ldots \ldots \ldots$ & 43.00 & 23.00 & 63.00 & 30.00 & 203.00 & 43.00 & $\ldots \ldots 23.00$ \\
\hline WYOMING $\ldots \ldots \ldots \ldots \ldots$ & 43.00 & 22.00 & 63.00 & 30.00 & 203.00 & 43.00 . & $\ldots 23.00$ \\
\hline NATIONAL CAPITAL ........ & 42.00 & 22.00 & 62.00 & 29.00 & 202.00 & 42.00 . & $\ldots 22.00$ \\
\hline NORTH CENTRAL....... & 42.00 & 22.00 & 62.00 & 29.00 & 202.00 & 42.00 & $\ldots 22.00$ \\
\hline UNSECTIONED $\ldots \ldots \ldots \ldots \ldots$ & 40.00 & 20.00 & 60.00 & 27.00 & 200.00 & 40.00 . & $\ldots .20 .00$ \\
\hline
\end{tabular}

